\title{
PROFESSIONAL ACTIVITIES OF LATVIAN BORN LITHUANIAN ARCHITECT AND ENGINEER KAROLIS REISONAS (1894-1981) IN ŠIAULIAI
}

\author{
SIGITAS VLADAS SALADŽINSKAS \\ Lithuanian Society for Engineering Graphics and Geometry \\ (Vilnius, Lithuania) \\ KRISTINA VAISVALAVIČIENE*** \\ Vytautas Magnus University (Kaunas, Lithuania)
}

Summary. The article introduces the life of not well-known in Latvia Latvian born Lithuanian Karolis Reisonas (in Latvian: Kārlis Reisons; 1894-1981) and his professional activities in Šiauliai city, as well as highlights the main features of the architect's creative work and the importance of his work in the history of Lithuanian architecture. K. Reisonas was one of the most prominent creators of modern architecture of the 20th century during interwar period in Lithuania. He is the author and co-author of representative buildings in the cities of Lithuania, as well as in Riga and Adelaide (Australia). K. Reisonas graduated from Riga Real School (1913) and St. Petersburg Institute of Civil Engineers (1920). He has worked as the Engineer of the Šiauliai city and Head of the Construction Department of the Municipality (1922-1930), the Director of the Tenth ${ }^{1}$ Courses of Šiauliai Construction (1925), later - the Director of the Siauliai Vocational School (1926), and an Advisor of Lithuania Chamber of Agriculture (1927-1928). Fourteen building to his design in Kaunas and Šiauliai cities are included in the list of cultural values of Lithuania. K. Reisonas' early projects are characterized by historicism, eclectic elements, of «brick style». Later projects have the features of aesthetic rationalism, functionalism, and adaptation to urban and cultural-historical context. After the Second World War, he and his family immigrated to Germany, later Adelaide in Australia, where he participated in the life of the Adelaide Lithuanian community.

1 The Tenth-(Lithuanian - dešimtininkas) - builder work groups, brigade of ten persons.

* Corresponding author.

E-pasts: kristina.vaisvalaviciene@vdu.lt 
Keywords: Karolis Reisonas, Latvian architects in Lithuania, architecture of Lithuania, Šiauliai city.

\section{Introduction}

The aim of the article is to introduce the life and professional activities of a famous engineer and architect of Lithuania, Karolis Reisonas, as well as to update the architectural heritage and the importance of his work in the history of Lithuanian architecture.

The architect and Leader of the Šiauliai Construction Department K. Reisonas was one of the most prominent architects creating the architectural identity of Šiauliai city during the inter-war period. Researching and promoting his works is especially relevant today, as in recent years in Lithuania significant steps have been taken to bring the modern architecture of the interwar period to the UNESCO World Heritage List [1]. Fourteen of buildings in Lithuania designed by him are included in the list of cultural values of Lithuania.

The Latvian origin of $K$. Reisonas provokes the question whether the architect's work in Lithuania was of interest to the Latvian community and whether he communicated with his colleagues - Latvian architects. So far, the research in this direction has not been done, therefore the authors of the article looked at the work of $K$. Reisonas in the reception of the Latvian press in the interwar period of the 20th century.

Sigitas Vladas Saladžinskas, one of the authors of the article, has studied K. Reisonas' biography and works in Šiauliai city as well as in other cities [2; 3], whereas the architect's creative period in Kaunas has been studied by historians Jolita Kančiene [4] and Morta Baužiene [5]. Articles of other authors (V. Petrulis, M. Dremaite, and G. Jankeviciute) analyse only isolated objects in Kaunas [6] and are fragmented in relation to the whole work and biography of $K$. Reisonas. In previous publications, there have been factual errors, unreasonable interpretations, so this article provides most up-to-date, more precise and complementary information about the architect.

\section{The family, studies and beginning of professional activities of Karolis Reisonas}

Karolis Reisonas was born on 26 April 1894, in «Inčas», in Pabaži parish (at present - Saulkrasti city [7]. His parents - Sìmanis Reisons and Minna Zvaigzne - got married in Pèterupe Evangelical Lutheran Church in 1892, and their two children - the son Kärlis (Karolis) and daughter Anna (born in 1903) were baptized in the mentioned church. Simanis
Professional activities of Latvian born Lithuanian architect and engineer Karolis Reisonas (18941981) in Šiauliai 
Reisons - the owner of a sailboat, a member of the Pèterupe Fisherman's Association - was an honourable resident of Pabaži parish, devoted much attention to the education of children. Private school operated at his home (1912-1933).

The upcoming engineer and architect, Karolis Reisonas, studied at private school until 1905, later joined the 5th Grade of the Realschule (secondary modern school) of Tsar Peter the Great [8]. In 1913, he completed the seventh additional grade of this school [9]. Touring with some of the school's mates - Eduards Malts, Jānis Eduards Staklis (who subsequently took part in the development of the Latvian railway infrastructure), and others - he went to the capital of Russia - St. Petersburg at that time [10]. K. Reisonas joined the St. Nicholas I Institute of Civil Engineers. The First World War and the October Revolution interrupted the progress of the future engineer a bit, but he managed to avoid mobilization and successfully graduated from the special department of this institute in 1917. In the years 1919-1920, he continued his studies in the Faculty of Architecture. After studies, K. Reisonas worked until the end of 1921 as an Assistant Professor of the Department of Civil Architecture of P. Dimitrijev [11] and as the Engineer of the Petrograd district, and later returned to an independent Latvia.

In 1922, having received a passport of a citizen of Latvia [12], the young engineer tried to get a job in his home country, but he did not succeed. Soon, a professional career opportunity arose in Lithuania in April 1922, K. Reisonas began to work in the municipality of Šiauliai, where he took the position of Engineer and Head of Construction Department [13].

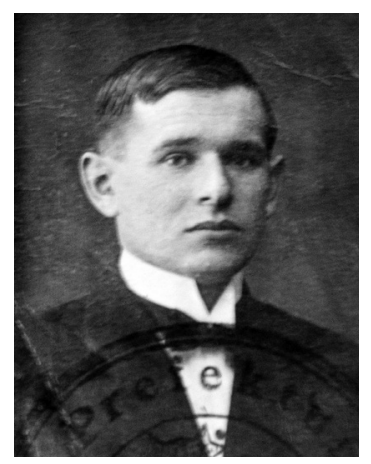

Figure 1. Photo from K. Reisonas' passport (1922) [12].

It is not really known what prompted the Latvian citizen to go to Šiauliai city and when he learned the Lithuanian language. After some years spent in Lithuania, he had already mastered the Lithuanian language very well - he published articles in the Lithuanian press, published study books, participated in various conferences and congresses. In one 
of the interviews, $K$. Reisonas' daughter Renata mentioned that before her parents got married, Lithuanian language to his father was taught by her mother - then a student in the Faculty of Law of the University of Lithuania - Elena Butnevičiūtè [14]. K. Reisonas received a permission from the Bishop of Rome to marry Elena, and they got married in Kaunas city in 1930 [15]. Both children - daughter Renata (born in 1931) and son Irvis (born in 1934) were born in Kaunas city.

K. Reisonas had contact with the Lithuanians already in Realschule (secondary modern school) of the Tsar Peter the Great, where many Lithuanian children studied and well-known Lithuanian mathematics teachers and authors of study books worked. Writer Pranas Mašiotas (1863-1940) worked in the school from 1892-1915 and Marcelinas Šikšnys (1874-1970) worked in the school from 1899-1915. They had founded the Lithuanian Cultural Society in Riga and secretly taught their mother language to children. During K. Reisonas' study years in Petrograd, many Lithuanians also studied there: the future architect of Kaunas - Antanas Jokimas (1894-1964; graduated in 1921), Grigorijus Gumeniukas (1892-?; graduated in 1917), Aleksandras Gordevičius (18911941; graduated in 1918), Stasys Kudokas (1898-1988; graduated in 1918), and others. With the latter, K. Reisonas' collaborated during designing and construction of the Šiauliai Drama Theatre, but with Grigorijus Gumeniukas he designed the Kaunas Cinema «Forum» (1929-1930). It is possible that the school and study mates helped to find work in Šiauliai.

The position of Head of the Šiauliai Construction Department was difficult, the scope of work was wide. During the First World War, the city had lost about $65 \%$ of the buildings, the population had decreased by three quarters, but at the beginning of the 20th century, Šiauliai began to grow rapidly [16]. K. Reisonas had to supplement and reorganize the preliminary plan for the reconstruction of the city several times (1922; 1924; 1927), which was approved by the Šiauliai City Municipality Board in 1920 [17].

As the city grew rapidly, there was a lack of specialists, therefore, $K$. Reisonas organized a training for land surveyors and other specialists who could work in construction. A drawing room was established in Šiauliai, and in 1925, K. Reisonas founded and began to run The Tenth courses in construction [18]. Soon the Šiauliai Vocational School (1926) was opened, where wood processing specialists were prepared [19]. Head of the Construction Department K. Reisonas was appointed the Director of the school. Since 1927, the supervision of the vocational school had been transferred to the Lithuanian Ministry of Education it was one of the first public vocational schools in Lithuania. During the directorship of $K$. Reisonas, the school worked according to the curricula and study programs worked out by its masters and educators, as it was
Professional activities of Latvian born Lithuanian architect and engineer Karolis Reisonas (18941981) in Šiauliai 
only in 1931 that the Lithuanian Ministry of Education approved general regulations for vocational schools.

The director of a vocational school received only a symbolic salary, but he was revered for diligence, sincerity and respect for colleagues [20], however, despite that, he had to resign soon, because according to the laws of the Republic of Lithuania only Lithuanian citizens could run a state institution. After K. Reisonas' resignation from the post of the director, some teachers retired from the school. The fact that K. Reisonas was not only one of the best public engineers, but also a great personality, was told by former Burgomaster of Šiauliai Jackus Sondeckis (1893-1989). He emphasized that among the many employees K. Reisonas stood out due to his stubbornness, awareness of duties and the ability to communicate [21].

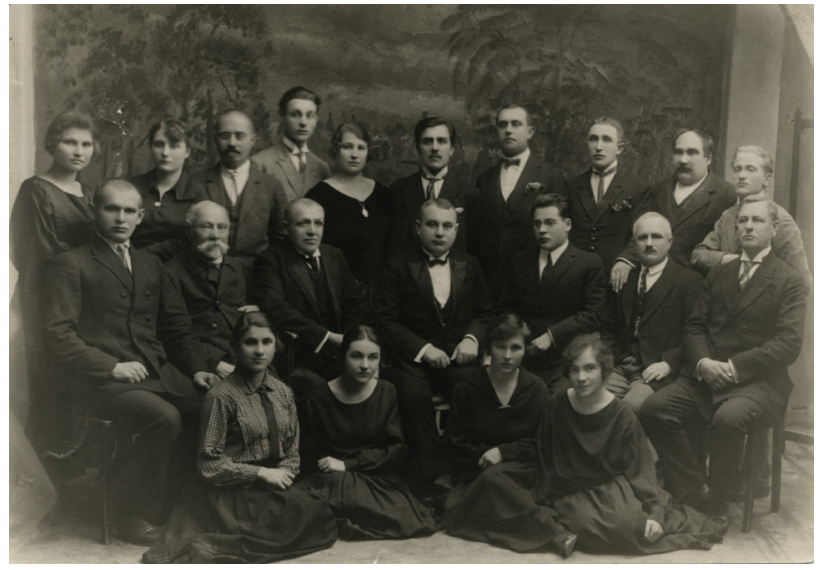

Figure 2. Employees of the Šiauliai city Municipality [22].

The foreign citizenship was an obstacle for talented specialist and organizer of studies K. Reisonas more than once. He repeatedly sought to obtain the Lithuanian citizenship [22], but the answers were long negative. Only after 10 years spent in Lithuania and marriage with a Lithuanian on 29 December 1932, K. Reisonas became a citizen of Lithuania [23].

In spite of certain limits, K. Reisonas' field of activity in Lithuania only expanded. At the invitation of the Ministry of Agriculture in 1927-1928, the Cabinet of Ministers authorized the Šiauliai city engineer K. Reisonas to work as a consultant for the Construction of Lithuanian Agriculture [24], but in 1929, he was appointed Head of the Department of Construction of Lithuanian Chamber of Agriculture [25]. 


\section{Study books written by Karolis Reisonas}

While working in Šiauliai, K. Reisonas began publishing articles on the development of the Šiauliai city, on rural construction issues, and prepared two study books on the construction of commercial buildings and residential buildings in rural areas. These were the first study books of such type in the Lithuanian language.

In 1926, the Department of Agriculture issued K. Reisonas' extensive study book (254 pages) «Žemés ūkio statyba» («Agricultural Construction»). The study book was intended for The Tenth courses in agricultural construction and visitors of the courses in Šiauliai and Kaunas. There were 357 drawings in three parts of the book. The first part analyses the peculiarities of Lithuanian farmers' houses, gives an advice on how to properly choose the place for the most important economic buildings and how to rationally place them, emphasizes the importance of ecology and sanitary requirements. Later, Reisonas' article on the subject was published also in the press [27]. The second part of the study book provides a brief overview of agricultural construction, with a particular focus on refractory structures. At that time, the development of cement in Lithuania was not yet restored, therefore $K$. Reisonas also received a criticism for promoting modern concrete technologies in rural construction. Professor Pranas Jodele (1871-1955), a reviewer of the study book, wrote that the author of the book had paid little attention to the construction of bricks, but, in his opinion, modern concrete bricks in the field of «hygiene and polythekonomy» do not fit into the Lithuanian countryside. According to the reviewer, the suggestions of the author of the study book are most suitable for «exemplary not ordinary farms», but the given estimates are too complicated to be understood by landowners or the Tenth Course visitors [28]. Professor P. Jodele was votary of burnt brick buildings and advocated the Swedish engineer Gerard's method - the construction of walls with air slots. Although the critic was partly right the construction of concrete was both more expensive and more complicated, when valuated retrospectively, it is unlikely that the «votary» criterion for growing Lithuania should be regarded as a deficiency. The author of the book sought to provide comprehensive construction cost information so it would be understandable not only for the builders but also for the owners of the houses.

The third part of the book gives interpretation of five typical residential house projects suitable for farms of different sizes. The design of each type of dwelling house was generalized with an artistically executed perspective view of the building. It should be emphasized that these projects focused not only on rationality and modern technology, but also on aesthetics. The movement of national awakening at the beginning of 
the 20th century aroused interest in folk art - architects, artists were encouraged to promote it and use it in their works. Therefore, in the Reisonas' study book, typical Lithuanian folk art elements appear featured by famous Lithuanian artists: Paulius Galaune (1890-1988) and Vladimiras Dubeneckis (1888-1932). After the restoration of independence of the country, the Lithuanian Company of Experimental Technologies for Monuments Restoration paid attention to the historical significance of this study book, its artistic and residual value, therefore, in 1990, it was issued repeatedly with photography.

The second K. Reisonas' study book «Molio statyba» («Clay Construction») (52 pages) was also prepared in Šiauliai city. It was issued in 1928 by the Lithuanian Chamber of Agriculture. The book is addressed to farmers and rural masters, it provides 42 illustrations. By striving to make the study material visual and simple, the drawings are executed using simple axonometric projections, the interior is reproduced using a central perspective. At the end of the 1920s, clay construction in Lithuania was promoted as an inexpensive alternative to construction of refractory materials, especially in places rich with clay resources. The book influenced the spread of clay buildings, including important buildings like barns throughout the Šiauliai region and beyond.

\section{Šiauliai - a city that raised from the ashes}

During the work in Šiauliai city, K. Reisonas devoted his attention to the restoration of the central part of the city. It was allowed to build only two and three storey houses there, covering them with refractory materials. The area approved for a brick building was five square kilometres. The construction of large stores, public and apartment buildings was started. In 1927, there were only $15 \%$ masonry buildings of which $54 \%$ were single storey, $35 \%$ two-storey, and $10.1 \%$ three-story buildings.

Following K. Reisonas' projects, 18 significant masonry buildings were built, including four cinemas: «Spindulys» (1922), «Rekord» (1922), «Marsas» (1927), and «Splendid palace» (1927) (later renamed «Kapitol») - the most modern one in Šiauliai - with a spacious 450 -seat auditorium, and interior decorated with luxurious balconies - for a long time was one of the most festive public spaces in the city. Not only films, but also theatrical performances were shown in this theatre, solemn public events took place.

K. Reisonas' first realized project in Šiauliai was the eclectic twostory building (1922, the corner of Vasario 16-osios and Vilniaus Street) owned by Šiauliai entrepreneur Vladas Vaitkus. The above mentioned «Spindulys» cinema was located on the second floor of the building. 
Unfortunately, in the beginning of the 1960s, the building was destroyed by a fire, and it was demolished. On the opposite side of the street, the house of Stasys Pocius, designed by K. Reisonas in 1922, is located. On the second floor of this building there was a community of wealthy townspeople «Šiauliečių klubas» («Šiauliai City People Club»). The corners of the building had a bay window and balconies on the first floor and a tower. The latter was intended to focus towards the nearby house of K. Ziva, which was also decorated with a tower. During the Second World War, the building was damaged, but in 1947 it was restored, except for the tower - it was removed. In April 2018, a memorial plaque (sculptor Kazys Bimba) was put up on the wall of this building, which reminds of the contribution of K. Reisonas in the architecture of the Šiauliai city [29].
Professional activities of Latvian born Lithuanian architect and engineer Karolis Reisonas (18941981) in Šiauliai

Figure 3. Buildings to the design by K. Reisonas: on the right - the house of $V$. Vaitkus; and on the left -the house of S. Pocius [30].

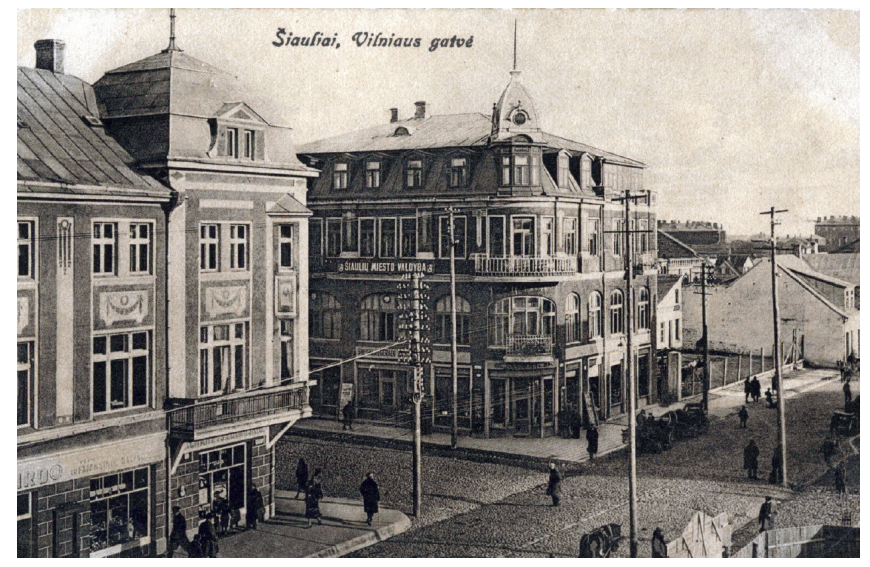

In Šiauliai, K. Reisonas began to design also industrial buildings. Chocolate and candy factories «Rūta» and «Birutè» are of architectural and historic significance. To his design two buildings of the factory «Rūta» at 133 Tilžes Street (1924; 1927) were built. The first building has not survived to this day, but the second one has been restored after the Second World War. The architecture of this building is the so-called «brick style». This technique was well known by the civil-engineers of St. Petersburg Institute. The composite solution of the main facade of the two-storey factory is symmetrical, brick walls without plaster, decor - restrained, based on geometrical drawings, reliefs and vertical bands. The building, which was located in the central part of the Šiauliai city, decorated Tilžes Street and advertised the factory «Rūta» and its products [31]. After the restoration of independence, the successors of the factory owners not only restored this building, preserving its «brick style», but also established a chocolate museum there in 2012. 


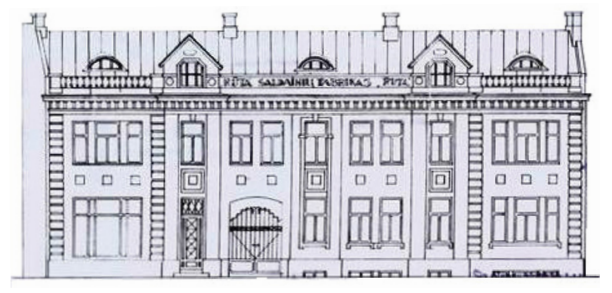

Figure 4. Project of Šiauliai

chocolate factory «Rūta» (1927)

[32].

The candy factory «Birutè» at 14 Stoties Street was also built in the so-called «brick style» (1925). In this two-storey building it was planned to have not only manufacturing premises, but also administration offices and a shop, and on the second floor an apartment for the factory director Vladas Vaitkus. After the war, the factory was reconstructed into an apartment building. Though it still reminds the $K$. Reisonas' project, its overall view is badly damaged - on the ground floor there are various companies, their owners decorate the facade of the building, each according to their own understanding, without coordinating their actions with the city artist.

As already mentioned, the largest number of buildings designed by K. Reisonas in Šiauliai city are public buildings. In 1926, he designed a three-level elementary school 129 Dvaro Street, which was named after the writer, Lithuanian national awakening activist, the author of the anthem of Lithuania, Vincas Kudirka (1858-1899). The school was opened in autumn 1930. At that time, it was one of the most beautiful and modern schools in the city - without classrooms and administrative rooms, with light and spacious corridors, provided with baths, showers, central heating and other amenities [33]. Vincas Kudirka Progymnasium is presently located there.

K. Reisonas also participated in the design of the Šiauliai Drama Theatre 155 Tilžés Street (1938). The author of the project - K. Reisonas' student $S$. Kudokas - was entrusted with the design of the theatre's interior. This project was developed when K. Reisonas was already living in Kaunas city. At the end of the Second World War, the building burnt down, and was later restored (architect Eduardas Budreika; 1918-2007), the original interior was not saved.

In terms of architectural style, the project of the Šiauliai City Museum-Library at Aušros Avenue, which K. Reisonas elaborated while living in Kaunas, is interesting. In this project, the features of modern architecture - rationalism and functionalism - are already visible. Although the foundation stone of the museum-library was solemnly placed in 1931, the building was unfortunately not built, as the changed city authorities decided that a school building is more necessary. 
It is not exactly clear how many private houses have been designed by $K$. Reisonas in the Šiauliai city. But one of them is the house 89 Vytauto Street (1925-1927) of the wealthy lawyer and Burgomaster of the Siauliai city, later Head of the City Council Kazimieras Venclauskis (18801940). Among other houses it stands out with the impressive architecture and is considered one of the examples of modern architecture of the inter-war period in the Šiauliai city. The building has a rectangular plan, a trapezoid bay window is designed in the main facade, the entrance is accentuated with a tower. The side facades are almost symmetrical. The two-storey building has a surrounding balustrade. Currently, one of the departments of the Šiauliai Museum «Aušros» is located in the building.

K. Reisonas' creative work associates with Šiauliai and was dedicated to perpetuation of Lithuania's independence efforts. Special honour and historical memory is cherished by the Siauliai Monument of Independence, located on a small hill in the western part of the city. The locals call this place the Hill of Rebels, which is reminiscent of the brutal repression of the Tsarist Russian gendarmerie against the disobedient people. Here, in 1863 , in the well-visible place from the city centre the gallows were set up [35].

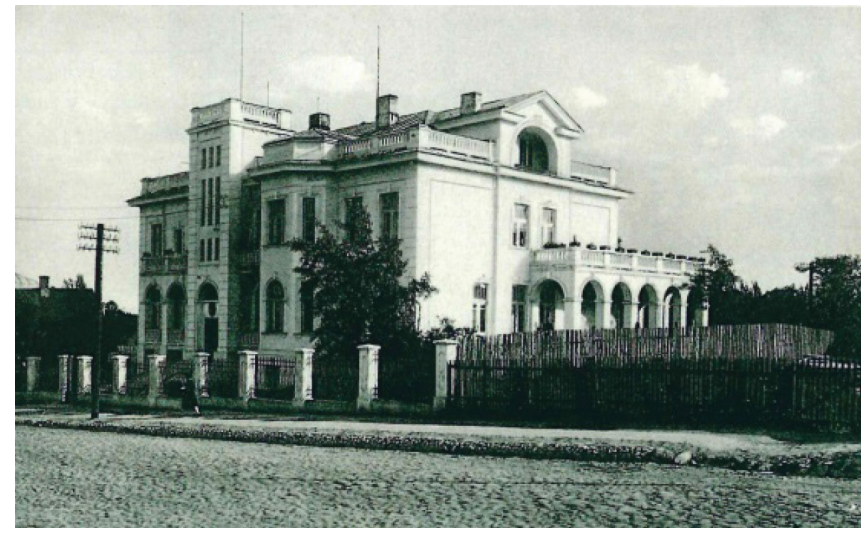

Figure 5. The house of lawyer Kazimieras Venclauskis [34].

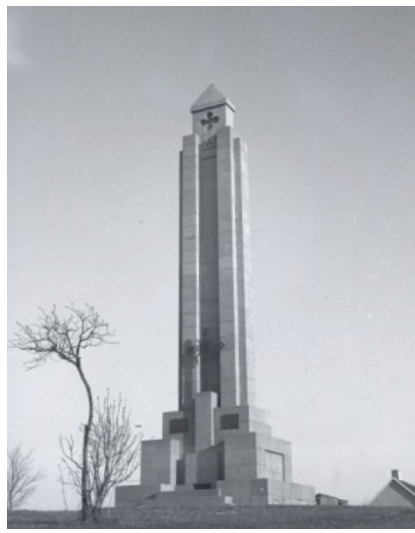

Figure 6. The Šiauliai Monument of Independence on the Hill of Rebels [36].

These final events left deep traces in the memory of people. The idea of installing a monument on the Hill of Rebels has already occurred in the first years of Lithuania's independence. In 1927, the place and the foundation stone of the monument were consecrated, with the participation of the President of the State Antanas Smetona (1874-1944) [37]. Initially, the project for the construction of the monument was commissioned to sculptor Juozas Zikaras (1881-1944). The sculptor made a 
model of the monument (now it is located in the Šiauliai Museum «Aušros»), but charged too much, so the deal was stopped. The project was taken over by K. Reisonas. Although he was already aware of his transfer to Kaunas, he showed great understanding and altruism - he not only developed the project, but also renounced the honorary. The monument was built in 1931, but for several reasons it was unveiled on 30 May 1935. The drawings of the design of the monument that were preserved in the archives were not signed, but the fact that the author is $K$. Reisonas testify both publications in the press of that time [38] and the document on the unveiling of the monument, which was found during the restoration of the monument, as well as the memories of the local people about the Latvian author of the monument. The composition of the monument masses of flattened rectangular parallels - reminds the architect's later works: the podium of the Freedom Monument of Kaunas, the Christ's Resurrection Church in Kaunas, Kaunas Evangelical Reformed Church, as well as the Christ the King Church in Riga. The Šiauliai Monument of Independence has an abundance of national, state and sacred symbols: the 14 meter high upright obelisk is decorated with a national-style roof, a four-leaf clover niche with an electric light bulb lit up by the colours of the national flag of Lithuania, the columns of Gediminas family (Gediminaičic stulpai). The upper horizontal cross-section of the monument captures a details of the coat of arms of Lithuania - the symbolics of double cross (Vyčio kryžius). There are bronze plates attached to the monument

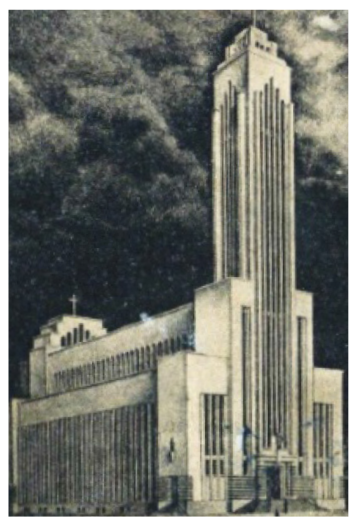

Figure 7. The Christ's Resurrection Church in Kaunas [39].

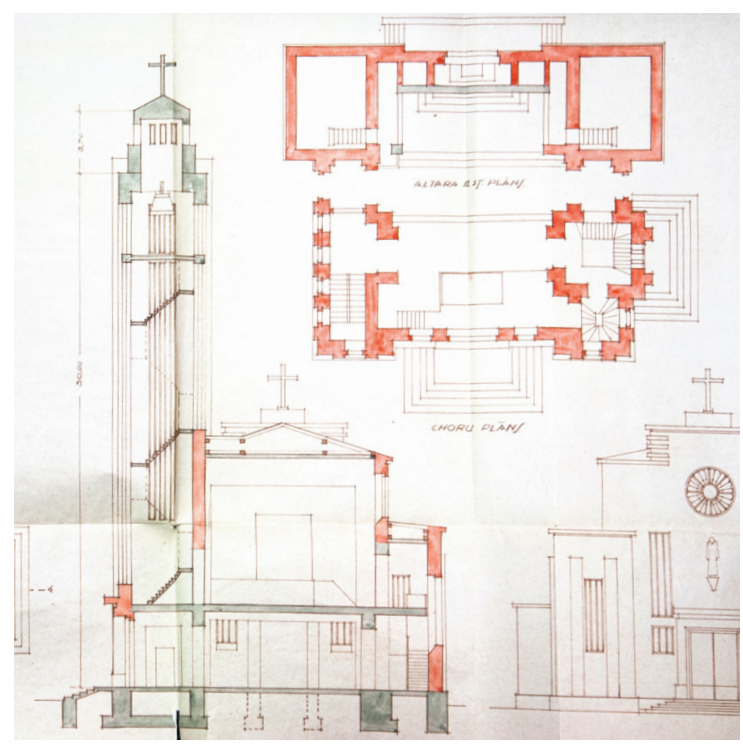

Figure 8. Design of Christ the King Church in Riga [40]. 
with the surnames of the rebels murdered on this hill and patriotic dedications. The remains of the ashes found on the Hill of Rebels were buried in the niche of the podium. After the Soviet occupation in 1940 and after the Second World War, the monument was reconstructed several times attempting to erase from the memory of people the idea of independent Lithuania and to use the events of the past for occupation propaganda. After restoration of the Republic of Lithuania, the monument was restored and re-veiled in 1992 (to the measures of architect Apolonija Nisteliené) [41]. The Monument of Independence and two other objects designed and preserved by K. Reisonas - Šiauliai Candy Factory «Rūta» and Kazimieras Venclauskis House - are included in the Lithuania Real Cultural Property Register.

\section{Conclusions}

K. Reisonas' creative and administrative work in Šiauliai, Lithuania (1922-1930) was productive. The buildings by him in the Šiauliai period are characterized by historicism, eclectic elements, «brick style». In the city that emerged from the debris of the First World War, around 18 masonry buildings were built to K. Reisonas' projects. Typical projects of wooden houses were used by a large number of Šiauliai families. Only eight of the significant objects designed by K. Reisonas were preserved or restored after the Second World War. Three of them are currently included in the Register of Immovable Cultural Valuables of the Republic of Lithuania and are protected from various types of «reconstructions».

Awaiting the centenary of the Republic of Latvia and the Republic of Lithuania, it should be noted that the architect of Latvian origin is the author of three particularly important monuments of independence of Lithuania: the Šiauliai Monument of Independence, the Freedom Monument in Kaunas, and the Memorial Christ's Resurrection Church in Kaunas. The echoes of the architect's creative and human intentions are found both in Latvia and in far-off Adelaide.

The highly qualified specialist $K$. Reisonas also made a great contribution to the development of Lithuanian agricultural construction: he founded and managed the Tenth Courses of Construction and Craftsmen, expanded the range of construction workers; his study books on agricultural construction were the first of the kind in the Lithuanian language.

The versatile personality of $K$. Reisonas is greatly illustrated by the exlibris, drawn in 1928 by his friend, Šiauliai artist Gerardas Bagdonavičius (1901-1986). The centre of it features an outstanding building that emphasizes the architect's main goal - to create a monumental building
Professional activities of Latvian born Lithuanian architect and engineer Karolis Reisonas (18941981) in Šiauliai 
project. The drawing is surrounded by tools of the architect, engineer and teacher, from which K. Reisonas did not part until the end of his life.

Architect $K$. Reisonas was personally known to Indrikis Blankenburgs (1887-1944), Latvian architect, graduate of the Riga Polytechnic Institute (1913). Both architects designed the Christ the King Church in Riga, 86 Meža Avenue (1934-1935), and this is the only known project by K. Reisonas in his native Latvia.

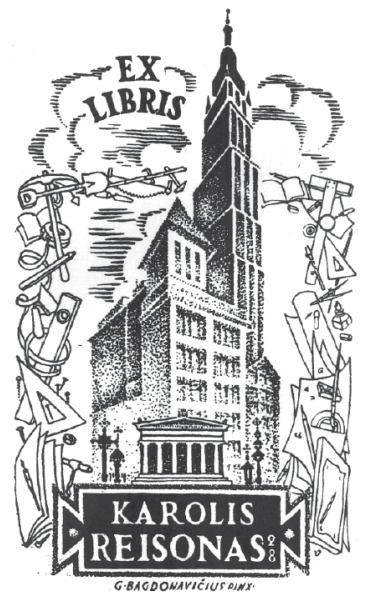

Figure 9.

K. Reisonas'

exlibris.

Author Gerardas Bagdonavičius (1928) [42].

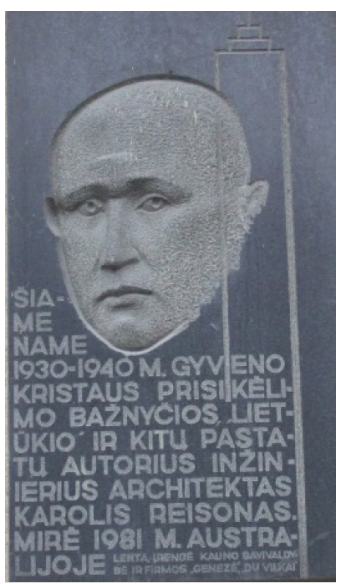

Figure 10. Memorial plaque to K. Reisonas in the Kauna city (arh. L. Strjoga) [43].

Not only the buildings and drawings that have survived to this day, but also the memorial plaques, which were erected in Kaunas and Šiauliai cities, show and remind of $K$. Reisonas' life and work. His works are mentioned in the history of architecture, at photo exhibitions, seminars and conferences. Exhaustive information and visual material on valuable architectural buildings are available in the database of the Register of Immovable Cultural Valuables of the Republic of Lithuania.

In the Latvian press of the inter-war period of the 20th century, relatively few K. Reisonas' works in Lithuania are reflected, more respected is his work in Kaunas. It is believed that the subsequent study of private contacts of $K$. Reisonas with his Latvian counterparts will open new pages of the architect's creative biography and enrich the history of Lithuanian and Latvian architecture, therefore the authors continue writing about his life and performance in the architecture of Kaunas (1930-1940), Panevéžys (1940-1944) and Adelaide (1949-1981). Much of $K$. Reisonas' personal archive is stored in the archives of his relatives, and friends in Adelaide and elsewhere.

Both K. Reisonas children follow the footsteps of their farther: his son Irvis, - at the Adelaide College had unusual abilities [44] and has become an engineer; his daughter Renata studied architecture [45]. Famous 
Lithuanian architect K. Reisonas died at the age of 87 on 17 July 1981, and was buried in Centennial Park Cemetery in Adelaide. The Lithuanian press in Adelaide published the In memoriam where he was named the great patriot of Lithuania «whose various buildings, schools, hospitals, churches will stand for a long time and proclaim the talents of their creator [46].»

For the merits to Lithuania K. Reisonas was awarded with the 4th Class Order of the Lithuanian Grand Duke Gediminas (1933), the 3rd Class Order of Vytautas the Great (1938), and the Lithuanian Independence Medal, which was founded in 1928 in honour of the 10th anniversary of the Republic of Lithuania.

\section{LIST OF SOURCES AND LITERATURE}

[1] Optimizmo architektūra: Kauno fenomenas, 1918-1940. Vilnius: Lapas, 2018, 299. lpp.

[2] Saladžinskas, S. Reisonas ir jo brèžinių parinkimo ypatumai. Inžineriné ir kompiuteriné grafika: konferencijos pranešimų medžiaga. Kaunas: Technologija, 2011, 5.-11. lpp. Nuo paminklo žuvusiems už Lietuvos nepriklausomybę Šiauliuose iki prisikèlimo bažnyčios Kaune. Mokslo ir technikos raida Lietuvoje. Vilnius: Vilniaus Gedimino technikos universitetas, 2009, [T.] 13, 283.-294. lpp.

[3] Saladžinskas, S. Paminklas 1863-1864 m. sukilimo aukoms Šiauliuose ir architekto Karolio Reisono palikimas. Žemaičiu Žemé. 2013, Nr. 1, 40.-47. lpp.

[4] Kančienè, J. Architektas Karolis Reisonas. Sēr. «Lietuvos architektai». Kaunas: Geltona, [b. g.]. Prisikèlimo bažnyčia. Archiforma. 1999, Nr. 3, 84.-86. lpp. Laikinosios sostinès architektas. Kauno diena. 02.05.1994., 23. lpp.

[5] Baužienè, M. Didžiausio Lietuvos nepriklausomybès dešimtmečio paminklo autorius. Žemaičiu Žemé, 2007, Nr. 4, 46.-50. lpp.

[6] Optimizmo architektūra: Kauno fenomenas, 1918-1940. Sast. M. Drèmaitè. Vilnius: Lapas, 2018.

[7] Pēterupes Luterāṇu Evanǵēliskās baznīcas grāmata. 1894, ieraksta Nr. 26. www.raduraksti.lv

[8] Latvijas Valsts vēstures arhīvs (turpmāk - LVVA), 247. f., 1. apr., 30. l., 19. lp. o. p.

[9] LVVA, 247. f., 1. apr., 40. 1, 25. lp.

[10] Stakle, J. V. Manas gaitas un pieredzējumi Latvijas atbrīvošanas karā. Dzelzcelnieks Trimdā, 1982, Nr. 30, 8. lpp.

[11] Kauṇas reǵionālais valsts arhīvs (turpmāk - KRVA), 219. f., 1. apr., 506. l., 79.-80. lp.

[12] LVVA, 2996. f., 16. apr., 8233. 1., 1. lp.

[13] KRVA, 219. f., 1. apr., 508. 1., 1. lp. o. p. 
[14] Prišmantienè, V. Prisikèlusi kartu su tauta. Respublika. 17.09.2011. Pieejams: http://www.respublika.lt/lt/naujienos/kultura/kulturos_ naujienos/prisikelusi_kartu_su_tauta [skatīts: 03.04.2018].

[15] Kauno Šv. Kryžiaus RKB Santuokos metrikų knyga, 1930. g., 105. lpp., ieraksta Nr. 63.

[16] Šiaulių miesto istorija (iki 1940 m.). Atb. red. L. Mulevičius. Šiauliai: Momentas, 1991, 131.-132. lpp.

[17] KRVA, 1622. f., 4. apr., 1094. l., 1116. l.

[18] KRVA, 219. f., 3. apr., 508. l., 27. lp.

[19] Lietuvas centrālais valsts arhīvs (Lietuvos centrinis valstybès archyvas; turpmāk - LCVA), 391. f., 5. apr., 187. l., 16.-17. lp.

[20] LCVA, 391. f., 5. apr., 187. 1., 29.-30. lp.

[21] Gyvenimas Lietuvai: knyga apie Jackų Sondecki, Šiaulių burmistrą, VLIK'o vadovybės narị, Lietuvos patriotą. Sast. J. Sereika. Šiauliai: Delta, 1993, 146. Ipp.

[22] Šaul̦u Aušras Muzejs (ŠAM) Poz161_I-av.

[23] LCVA, 394. f., 2. apr., 1416. l, 632. lp.

[24] LCVA, 1367. f., 9. apr., 19. 1, 167. lp.

[25] KRVA, 923. f., 1. apr., 545. 1, 239. lp.

[26] Statybos skyrius prie Žemès ūkio Rūmų. Ūkininko Patarejjas, 1929, Nr. 2, 55.-56. lpp.

[27] Reisonas, S. Ūkio sodybai vietos parinkimas. Ūkininko Patarejjas, 1928, Nr. 8, 419.-425. lpp.; Nr. 9, 468-486. lpp. [Avīzē norādīts nepareizs vārda burts - S. Reisonas].

[28] P. J. Inž. K. Reisonas. Žemès ūkio statyba: [recenzija]. Technika, 1927, Nr. 3, 94., 176. lpp.

[29] Iprasmintas žinomo tarpukario architekto atminimas. Pieejams: www. etaplius.lt, https://www.etaplius.lt/iprasmintas-zinomo-tarpukarioarchitekto-atminimas [skatìts: 26.04.2018].

[30] Atklātne. ŠAM IK-F1943_2-av.

[31] Drèmaitė, M. Progreso meteoras. Vilnius: Lapas, 2016, 279., 281. lpp.

[32] LCVA, 388. f., 2a. apr., 359. l., 7.lp.

[33] Š.M.B.I.B. D-ro Vinco Kudirkos pr. mokyklos atidarymas. Šiaurès Lietuva, 1930., Nr. 33, 4. Ipp. Ata. D-ro Vinco Kudirkos pr. mokyklos atidarymas. Šiaurès Lietuva. 10.10.1930., Nr. 35, 3. lpp.

[34] Atklātne no grāmatas «Senieji Šiauliai atvirukuose. 1902-1944». Šiaulių «Aušros» muziejus, 2006, 313. lpp. PK ŠAM.

[35] 1863-1864 metai Lietuvoje. Sast. V. Girininkienè. Kaunas: Šviesa, 1991, 56.-58., 63.-65. lpp.

[36] Fotoattēls: G. Bagdonavičus, 20. gs. 30. gadi. ŠAM F-FN 8335.

[37] T. S. J. E. Valstybès prezidentas Šiauliuose. Šiaulietis, 1927, Nr. 23, 1. lpp.

[38] Nepriklausomybės paminklas. Lietuvos Žinios, 1931, Nr. 131., 4. lpp.

[39] Nistelienè, A. Sena ir nesena istorija - kas ir dèl ko dejjo ranką prie paminklo. Šiaulių Naujienos, 04.12.1999., 10. lpp.

[40] Attēls no grāmatas «Su Jèzaus Širdies palaima». Kaunas, 1938.

[41] LVVA 2761. f., 3. apr., 13452. l. 
[42] ŠAM D-T 6764.

[43] Fottoattēls. K. Vaisvalavičiene (2018).

[44] Приход/The Parish. Pieejams: http://saintnicholasadelaide.org. au/?page_id=71 [skatìts 23.05.2018].

[45] Scholar New to English. The Mail. Adelaide. Saturday, December 27, Vol. 42, Nr. 2114, 1952, pg. 2. Pieejams: http://trove.nla.gov.au/ndp/del/ page/4736447?zoomLevel=1 [skatīts: 06.06.2018]

[46] Prišmantienè, V. Prisikèlusi kartu su tauta. Respublika. 17.09.2011. Pieejams: http://www.respublika.lt/lt/naujienos/kultura/kulturos_ naujienos/prisikelusi_kartu_su_tauta [skatīts: 03.04.2018].

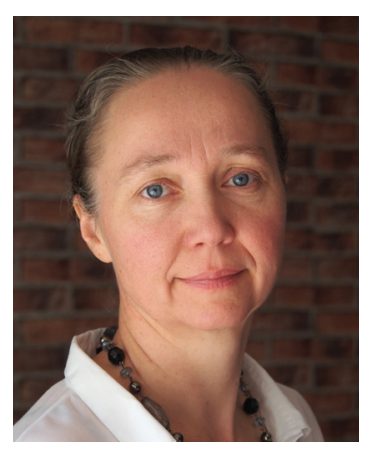

KRISTINA VAISVALAVIČIENĖ, $M g$. philol., $P h D$ student of Lithuanian philology in Vytautas Magnus University (Kaunas, Lithuania), administrator of the VMU Center of Letonics, member of the association «Lietuvos ir Latvijos forumas». Main academical interests: cultural relations between Lithuania and Latvia, Baltic literature, children literature and periodicals.

Address: Putvinskio Street, 210, Kaunas, LT-44243, Lithuania.

Phone: +370 61253317

E-mail: kristina.vaisvalaviciene@vdu.lt

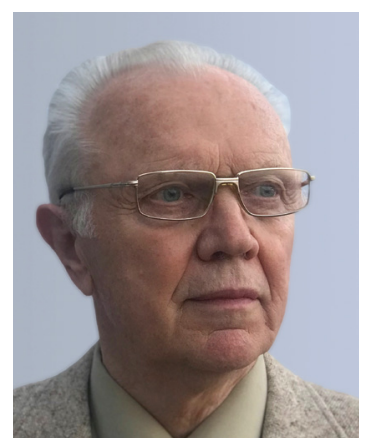

SIGITAS VLADAS SALADŽINSKAS, specialist of descriptive geometry, researcher of the Lithuanian architecture and culture, member of the Lithuanian Society for Engineering Graphics and Geometry, pensioner, emeritus expert teacher of mathematics and engineering design, the member of international association BALTGRAF, the member of Lithuanian Society for Engineering Graphics and Geometry. Main academical interests: the methods and development of mathematics and engineering design teaching, the history of architecture of Šiauliai and Panevėžys.

Adress: M. K. Čiurlionio str. 6-19, Vilnius, Lietuva

Phone: +37064751976

Sigits Vlads Saladžinsks, Kristina Vaisvalavičiené

Latviešu izcelsmes Lietuvas arhitekts un inženieris Kārlis Reisons (1894-1981) un viṇa profesionālā darbība Šauḷos

Raksts iepazīstina ar Latvijā maz zināma latviešu izcelsmes Lietuvas arhitekta un inženiera Kārḷa Reisona (Karolis Reisonas; 1894-1981) dzīvi un profesionālo darbību Šauḷos, kā arī aktualizē svarīgākās arhitekta daiḷrades mantojuma iezīmes un viṇa darbu
Professional activities of Latvian born Lithuanian architect and engineer Karolis Reisonas (18941981) in Šiauliai 
nozīmi Lietuvas arhitektūras vēsturē. K. Reisons bija viens no spilgtākajiem 20. gadsimta starpkaru perioda Lietuvas modernās arhitektūras radītājiem. K. Reisons ir reprezentatīvu celtṇu Lietuvas pilsētās, kā arī Rīgā un Adelaidā (Austrālija) autors vai līdzautors. Rīgas reālskolas (1913) un Sanktpēterburgas civilinženieru institūta (1920) absolvents K. Reisons strādāja par Šaul̦u pilsētas inženieri un pašvaldības Būvniecības nodaḷas vadītāju (1922-1930), Šaul̦u būvniecības desmitnieku kursu (1925), vēlāk arī Šauḷu arodskolas direktoru (1926), Lietuvas Lauksaimniecības kameras konsultantu (1927-1928). 14 no viṇa projektētām celtnēm Kauṇā un Šauḷos ir iekḷautas Lietuvas Kultūras vērtību reǵistrā. Agrīniem K. Reisona projektiem raksturīgs historisms ar eklektisma elementiem un tā sauktais «ḳieǵeḷu stils». Vēlākie projekti iezīmējas ar modernajai arhitektūrai raksturīgu askētisko racionālismu, funkcionālismu un piemērošanos pilsētbūvniecības un kultūrvēsturiskajam kontekstam. Pēc Otrā pasaules kara viṇš ar ǵimeni emigrēja uz Vāciju, vēlāk - uz Adelaidu, piedalījies Adelaidas lietuviešu kopienas dzīvē.

Atslēgas vārdi: Kārlis Reisons, latviešu arhitekti Lietuvā, Lietuvas arhitektūra, Šauli.

\section{Сигитас Владас Сададжинскас, Кристина Вайсвалавичиене}

\section{Литовский архитектор и инженер латышского происхождения Карлис Рейсонс (1894-1981) и его профессиональная деятельность в Шауляй}

Статья знакомит с жизнью и деятельностью малоизвестного в Латвии литовского архитектора инженера латышского происхождения Карлиса Рейсонса (Karolis Reisonas, 1894-1981) в Шауляй, а также актуализирует наиболее важные детали творческого наследия архитектора и значение его труда в истории архитектуры Литвы. К. Рейсонс был одним из наиболее ярких создателей современной литовской архитектуры в межвоенном периоде. К. Рейнсонс является автором или соавтором репрезентативных зданий в городах Литвы, а также в Риге и Аделаиде (Австралия). Будучи выпускником Рижского Реального училища (1913) и Санкт-Петербургского института Гражданских инженеров (1920), К. Рейсонс работал городским инженеров г. Шауляй и руководителем отдела Строительства (1922-1930), позже директором ремесленного училища г. Шауляй (1926), был консультантом Камеры Сельского хозяйства Литвы (19271-1928). 14 зданий, которые он проектировал в Каунасе и Шауляй, включены в регистр Культурных ценностей Литвы. Ранним проектам К. Рейсона присущ стиль историцизма с элементами эклектики и т. н. «кирпичный стиль». Для более поздних проектов характерен для современной архитектуры свойственный аскетичный рационализм, функциональность и приспосабливаемость к культурноисторическому контексту и градостроительству. После Второй мировой войны он вместе с семьей эммигрирует в Германию, затем в Аделаиду, , принимал участии в жизни литовского землячества Аделаиды.

Ключевые слова: Карлис Рейсонс, латышские архитекторы в Литве, литовская архитектура, Шауляй. 